\title{
Gościnność jako wartość w rozwoju młodego człowieka na przykładzie współczesnej literatury polskiej dla dzieci i młodzieży
}

\section{KEY WORDS}

hospitality, literature for children and teenager, safety, tolerance, cultural otherness

\begin{abstract}
Józefowicz Anna, Gościnność jako wartość w rozwoju młodego człowieka na przykładzie współczesnej literatury polskiej dla dzieci i młodzieży [Hospitality as a Value in the Development of a Young Man at the Example of Contemporary Polish Literature for Children and Youth]. Kultura - Społeczeństwo - Edukacja nr 2(10) 2016, Poznań 2016, pp. 137-150, Adam Mickiewicz University Press. ISSN 2300-0422. DOI 10.14746/kse.2016.10.11.

Considering the educational value of the category of "hospitality", I made attempts to a critical reflection on this issue in recent Polish literature for the young audience. The analysis has been subjected the prose in which the issue of hospitality takes on different meanings. First of all is mentioned of hospitality in dimension of culinary and sociosociable, in the sense of kind treat the "food and drink" (the most common understanding of hospitality, when care of the our neighbor is expressed through common eating the prepared food). Secondly is mentioned of hospitality in dimension of family, in the sense of hosting adult children. In this dimension I drew attention to first difficult relationship with the adopted child, when parents start by hosting it, to create a common nest. There is also one more understanding of hospitality, very timely in the current socio-political situation, the intensifying law concerning ethnic and religious minorities in Western Europe, the understanding of hospitality in aspect of cultural, the hospitality to the "other" - culturally different.
\end{abstract}

\section{Uwagi wstępne}

Z pewnością istotą edukacji jest przekaz wartości uniwersalnych, a więc prawdy, dobra i piękna, oraz wzorców osobowych (Banach, 2001; Puzynina, 1992; Olbrycht, 2000). Sam termin wartość rozumiem, za Januszem Homplewiczem, 
jako „(...) wszystko to, co dla człowieka przedstawia się jako cenne, w co chce angażować swe wysiłki i wolę”. Autor podkreślał: „(...) dążenie ku wartościom kształtuje człowieka, jest też $\mathrm{w}$ stanie przesądzać o jego wewnętrznym rozwoju, o jego przeżyciach, działaniach i całej postawie życiowej" (Homplewicz, 1996: 142). Powołując się także na słowa Dietricha von Hildebranda, który twierdził: „(...) człowiek nie może być moralnie dobry, dopóki się interesuje tylko tym, czy go coś zadowala lub jest mu miłe, zamiast spytać, czy to ma znaczenie samo w sobie, czy jest piękne i dobre, czy powinno być chciane ze względu na nie samo, słowem czy jest wartościowe" (Hildebrand, 1982: 10), uważam, że kategoria gościnności może być postrzegana jako wartość moralna, jako „dobro samo w sobie", a jej wartość edukacyjna w rozwoju młodego człowiek jest niekwestionowana.

Gościnność ma swoje źródło w wielowiekowej tradycji europejskiej. Łacina nadała słowu gość-hostis znaczenie podwójne, gdzie z jednej strony oznacza ono osobę obcą, cudzoziemca, nietutejszego, wędrowca, przybysza, którego wypada nakarmić i ogrzać (ghos - karmić, żywić), na którego się oczekuje, który przybywa w odwiedziny, a $\mathrm{z}$ drugiej strony, zastanawiające jest porównanie przybysza z wrogiem, z osobą nieprzyjazną, nieprzyjacielem (Brückner, 1974: 158; Bańkowski, 2000: 462). Podobne znaczenie miało greckie kseinos - prawo gościnności, najstarsze prawo, którego strzegł sam Zeus. Wśród starożytnych Greków jedną $\mathrm{z}$ podstawowych powinności, wynikającą z cnoty (arete) jako wartości moralnej, była zasada gościnności. Nakazywała ona niezależnie od sytuacji respektowanie przyjacielskich więzów łączących gospodarza i gościa. Gościnność jako wartość ustanowiła związki przyjaźni niejako rytualnej, które pozostały ważne dla kolejnych pokoleń i przestrzegane były także $w$ trakcie wojen, co widzimy chociażby w Iliadzie.

„Grecy często używali określenia philoxenía, co znaczyło umiłowanie gościaobcego, a miłość ta przejawiała się w specyficznym rodzaju gościnności. Zapraszając obcego na posiłek, nie dawali mu swoich własnych potraw, lecz produkty, tak, aby gość mógł przygotować sobie posiłek według własnych gustów i zwyczajów" (Środa, 2008: 40). Dziś powiedzielibyśmy, że uznawali prawo kulturowej odrębności i tradycji, z której mogli skorzystać w procesie akulturacji systematycznej (wzajemnego uczenia się od siebie).

Wskazana wyżej zasada gościnności nie była jednak dominująca. Zygmunt Gloger twierdził, że „(...) gościnność starożytna ciasne bardzo miała granice (...) z prawdziwą gościnnością spotykamy się w starożytności tylko u ludu izraelskiego, u którego wychodzono na spotkanie przybywającego wędrowca, obmywano mu nogi, stawiano posiłek, opatrywano jego służbę i zwierzęta" (Gloger, 1985: 207).

W Biblii gościnność jest odpowiednikiem greckiego wyrazu philoxenía, który oznacza miłość, sympatię, życzliwość wobec obcych przybyszów. Jeżeli powołu- 
jemy się na zapisy w Piśmie Świętym, naród żydowski okazywał troskę podróżnym bez względu na to, czy byli to krewni, czy obcy, oferując im gościnę, nocleg, a nawet odprowadzając kawałek w drodze powrotnej. Jehowa potępił Izraelitów za pośrednictwem proroka Izajasza za ich niegościnność, oświadczając, że na próżno zachowują post i biją przed Nim pokłony, skoro jednocześnie pozwalają, by ich bracia cierpieli na skutek braku pożywienia i dachu nad głową (Iz 58,3-7). Sam Chrystus często korzystał z gościnności tych, którzy rozpoznali w Nim posłańca Bożego: „Lisy mają jamy i ptaki nieba mają na odpoczynek, lecz Syn Człowieczy nie ma gdzie złożyć głowy” (Mt 8,20; Łk 10,38). Gościnność jest cechą oczekiwaną od chrześcijan, o czym pisał autor Listu do Hebrajczyków: „Nie zapominajcie o gościnności, bo dzięki niej niektórzy, nie wiedząc, podejmowali aniołów” (Hbr 13,2) oraz sam Jezus: „Więcej szczęścia wynika z dawania niż z otrzymywania" (Dz 20,35). Wskazówki powyższe musiał znać legendarny Piast Kołodziej, przyjmując nieznanych wędrowców na ucztę wydaną z okazji postrzyżyn swego syna, choć mimo znacznych starań obawiał się, czy wystarczy jedzenia dla wszystkich gości. Jak głosi legenda, wędrowcy okazali się Bożymi posłańcami i nagrodzili łaskawość i przychylność Piasta niekończącą się obfitością spiżarni. W epoce wierzeń antropomorficznych, jak pisał Ryszard Kapuściński, „(...) nie było wiadome, czy ten zbliżający się oto wędrowiec, podróżny, przybysz to człowiek czy bóg, do człowieka podobny. Ta niepewność, ta intrygująca ambiwalencja jest jednym ze źródeł kultury gościnności, nakazującej okazanie wszelkiej życzliwości przybyłemu, o do końca nierozpoznawalnej istocie" (Kapuściński, 2004).

O gościnności Słowian przeczytać można także u Johanna Gottfrieda Herdera: „(...) byli uczynni, gościnni aż do rozrzutności, byli miłośnikami wiejskiej swobody, ale przy tym ulegli posłuszni, byli wrogami rabunku i grabieży" (Herder, 1962: 326-327). W tym miejscu można jeszcze raz przytoczyć słowa Zygmunta Glogera:

(...) taką samą humanitarną gościnnością, jak Izraelici wśród ludów starożytnych, odznaczyli się Słowianie pośród późniejszych narodów Europy. Był zwyczaj stary i powszechny w narodzie polskim, że tak w świetlicy pana, jak w izbie kmiotka, na stole, nakrytym u pana białym obrusem lub barwnym kobiercem, a u kmiecia ręcznikiem, leżał wiecznie chleb i sól, z którymi przyjmowano gości w progu obyczajem odwiecznym. (...) stąd uczty liczne z powodu świąt uroczystych, imienin, zaręczyn, wesel, chrzcin, pogrzebów, nowosiedlin i przenosin, zapustów, okrężnego, łowów, objęcia urzędu ziemskiego. O którejkolwiek wreszcie porze przybyłeś w dom szlachecki, zawsześ bywał uraczony. (Gloger, 1985: 207)

Tak więc drzwi i bramy służyły nie tylko do zamykania się, ale do zapraszania w gościnę. „Droga (...) może być też traktem, którym idzie do nas ubrany w strój 
pielgrzyma któryś z bogów" (Kapuściński, 2004). Adam Mickiewicz w Panu Tadeuszu zaprasza do dworku w Soplicowie, wskazując na zawsze otwartą bramę: „(...) brama na wciąż otwarta przechodniom ogłasza, że gościnna i wszystkich w gościnę zaprasza”.

Analiza literatury polskiej na przestrzeni stuleci potwierdza, że gościnność wobec podróżnych była zwyczajem pożądanym. Przecław Słota w średniowiecznym wierszu $O$ zachowaniu się przy stole, który można oceniać z perspektywy współczesnej jako podręcznik $\mathrm{z}$ gatunku savoir vivre, zwraca uwagę na dobre obyczaje, jakie powinno się okazywać przy stole (m.in.: jedzenie drobnymi kęsami, czystość rąk). Jan Kochanowski we fraszce Na gospodarza mówi, że gościnność w parze ze szczodrością iść powinna. Zarówno dom Jana Kochanowskiego, jak i Mikołaja Reja to miejsca pełne ciepła, ostoje dobrych manier, rodowych tradycji, łaskawe dla przejezdnych. Tak samo hojni wobec weselników są chłopi w Weselu Stanisława Wyspiańskiego, jak też w Chłopach Władysława Reymonta.

Obecnie gościnność od słowa gościnny kojarzy się najczęściej z uprzejmością, częstowaniem posiłkiem przygotowanym osobie, która nas odwiedza. Wspólne zasiadanie do stołu, przygotowanie posiłku-strawy jest pewnego rodzaju wyrazem troski o drugiego człowieka, a proces ucztowania i biesiadowania pełni funkcję integrującą ludzi, funkcję więziotwórczą (Jędrych, 2014: 186). Nie bez przyczyny znaczenie dobrego przyjęcia, dobrej gościny podkreślają znane po dziśs dzień przysłowia: „czym chata bogata, tym gościom rada” (XIX wiek) czy „gość w dom Bóg w dom" (Rysiński, 1618; Świrko, 1985: 36).

Dziś obserwujemy jednakże coraz szersze rozmywanie społecznych więzi czy nawet zanik poczucia przynależności do danej wspólnoty. „Społeczeństwo globalne wysoce zurbanizowane i zindustrializowane przyczynia się do zatomizowania wspólnot (...)" (Cybal-Michalska, 2011: 22) jak twierdzi Agnieszka Cybal-Michalska. Autorka, powołując się dalej na przemyślenia Stanisława Ossowskiego, rozważa odczucie „próżni wartości” takiej osamotnionej jednostki w późnej ponowoczesności oraz jej marzenia o tworzeniu się grup dających odczuć bliskość, a raczej substytuty bliskości. Proponuje orientację na odpowiedzialność, współpracę i wiedzę (Cybal-Michalska, 2011: 30-35). Nawiązują do słów uprzednich, chciałam zwrócić uwagę na umiejętność wartościowania sztuki, w tym literatury pięknej, która to odgrywa szczególną rolę we wprowadzaniu młodych ludzi w świat wartości. Literatura piękna, jak twierdzi Joanna Papuzińska, jest „(...) nośnikiem modeli zachowań, a więc pewnych konstrukcji fabularnych, mogących stanowić punkt odniesienia dla wartościowania zachowań realnych oraz wyznaczyć ich kierunek" (Papuzińska, 1996: 43). Kierując się powyższym 
i mając na uwadze wartość edukacyjną kategorii „gościnność, podjęłam się próby krytycznego namysłu nad niniejszą kwestią w najnowszej literaturze polskiej dla młodego odbiorcy. Analizie została poddana proza, w której zagadnienie gościnności przybiera różne znaczenia.

\section{O gościnności jako poczęstunku}

Sądzę, że najczęściej rozumienie gościnności związane jest z przyjemnością biesiadowania, jedzenia, doświadczania radości spożywania. Sceny spędzania czasu za stołem, przyrządzania i częstowania potrawami są jednak nieczęste $\mathrm{w}$ powieściach $\mathrm{z}$ ostatnich lat przeznaczonych dla młodych czytelników. Niewiele miejsca poświęcono postawie gościnności wobec drugiego człowieka, zaproszeniu na herbatę, ciasto. To jakby pojawia się między wierszami, co można potraktować jako sprawę niegodną refleksji. Na co dzień niewielką wagę przykłada się do konwencji etykietalnych, dobrych zwyczajów, gestów, tak jakby były one sprawą nieco krępującą. „Ksawery zakaszlał i wykonał zapraszający gest. - Ale nie ma co rozmawiać na środku drogi. Zapraszam na herbatę, u nas goście to prawdziwa rzadkość, nawet tacy smarkaci” (Witek, 2013: 39). Jednakże od święta, czy kiedy wymaga tego wyjątkowa sytuacja, bohaterowie przyodziewają odświętne ubrania, czym potrafią zwrócić uwagę osób z boku.

Kiedy go zobaczyliśmy, od razu zrozumieliśmy, że staruszek musi mieć jakąś ważną sprawę, bo inaczej nie stroiłby się w garnitur w środku lata. Chcieliśmy go o wszystko od wejścia wypytać, ale ciocia chyba wyczuła nasze intencje. Odsunęła nas stanowczo na bok i zaprosiła pana Ksawerego na kawę na werandę. Do kawy dodała ciasto (...). (Witek, 2013: 93)

W powieści Agnieszki Wiszowatej Sam i Riko mama żartobliwie, ale jednak edukuje malutkiego jeszcze synka, jak to, zapraszając gości, należy mieć ich czym „ugościć”: „Musimy tylko zaprosić Jankę na kolejną wizytę. I może tym razem to my upieczemy ciasteczka" (Wiszowata, 2015: 22). Adekwatnie do omawianej sytuacji przytoczyć można dawne przysłowia zanotowane przez Samuela Bogumiła Lindego: „Gość nie z próżnymi rękoma najdzie u mnie wszystko doma” czy też „Gość który nic nie przyniesie, niech się prześpi w polu, w lesie” (Linde, 1855: 103).

Pojawia się także częsty obraz babci przygotowującej ciasto, która wyraża troskę o wnuki, bądź szacunek wobec gości, czasem nawet nieproszonych, częstując ich własnoręcznie upieczonymi smakołykami.

Nietrudno było zauważyć, że widok świeżego rabarbarowego ciasta i zaparzonej kawy przyciągnął ich z ogromną siłą. - Stasiu, toż poczęstuj panów ciastem! - nie wytrzymała 
ciocia Ula. - Na pewno z daleka przyjechali (...). Przybysze uśmiechnęli się przepraszająco. - A zaproszę, zaproszę (...). (Wiszowata, 2015: 122)

Podobnie bezinteresowna życzliwość okazywana przybyszom w rodzinie Borejków, w kolejnych tomach Jeżycjady Małgorzaty Musierowicz, stała się już legendarna. „Babcia Borejko zaraz zaprosiła pana Gruszkę do stołu. Gość spojrzał na nią z uznaniem i nie odmówił gorącej herbaty i domowego makowca" (Musierowicz, 2012: 236). Taki obraz jest powielanym stereotypem gościnności starszej pani - najczęściej babci lub cioci, gdyż jest niezależny od czasu akcji utworu, dotyczy postaci epizodycznych, jak też zaprzecza widzeniu takiej postaci jako niepowtarzalnej jednostki (Papuzińska, 1996: 100). Jednakże taki wizerunek zaspokaja psychofizyczną potrzebę bezpieczeństwa dziecka, prezentuje model rodziny, w której panuje atmosfera nasycona pozytywnymi uczuciami. Ciepła filiżanka mleka jest symbolem powrotu do czasów dzieciństwa, wspomaga mitologizację owych czasów jako arkadyjskich. „Ciabcia zaśmiała się cicho. - Chcesz ciepłego mleka? (...) Twoja mama zawsze lubiła wypić kubek ciepłego mleka przed snem. (...) Bo po tym się dobrze śpi i ma przyjemne sny" (Szczygielski, 2013: 52). Warto podkreślić jeszcze, iż ciepłe mleko, budyń, drożdżowe placki, makowce, własnej roboty sery, warzywa i owoce z własnego ogródka i sadu, pojawiają się na wiejskich stołach dziadków i nimi gości się dzieci przybywające do nich $\mathrm{z}$ odległych miast na kilkutygodniowe wakacje. „(...) babcia częstowała mnie czekoladowym budyniem. - Jedz, chudzinko, jedz - prosiła" (SzyszkoKondej, 2008: 70). Po takim „ekologicznym” żywieniu, detoksie od miejskich fast foodów dzieci same nie wyobrażają sobie powrotu do „(...) odgrzewanych papek ze słoików” (Witek, 2013: 71), co jeszcze bardziej cieszy babcie, które potrafią skwitować swoje racje odnośnie żywienia: „Niech się najedzą dobrych rzeczy, bo jak wrócą do miasta, to nie wiadomo, co ich czeka" (Witek, 2013: 131). Takie fragmenty realizują założenia określone $\mathrm{w}$ podstawie programowej dotyczące edukacji zdrowotnej, pomagają dziecku zrozumieć, jak głosi zapis w podstawie, jak istotny jest nawyk dbania o zdrowie, „(...) jakie znaczenie dla zdrowia ma właściwe odżywianie się oraz aktywność fizyczna" (Podstawa programowa kształcenia ogólnego dla szkół podstawowych z dnia 23 grudnia 2008 r. I etap edukacyjny: klasy I-III, edukacja wczesnoszkolna, 13-14). Można śmiało stwierdzić, że wyżej przytoczone cytaty nawiązują także do znanego przysłowia Decimusa Juniusa Juvenalisa „W zdrowym ciele zdrowy duch”. Przyrządzanie pełnowartościowych posiłków jest akcentowane w literaturze dla młodego odbiorcy, mało tego, wspólne posiłki łagodzą obyczaje, poprawiają humory, a nawet potrafią rozładować emocjonalne napięcie: „(...) goście więdli przy stole. Wejście mamy z pachnącą rybą uratowało ich przed niechybnym szaleństwem" (Ostrowicka, 2002: 30). 
Wyjątkiem, odstępstwem od roli gotującej i następnie częstującej babci jest postawa niezależnych starszych pań z powieści Małgorzaty Gutowskiej-Adamczyk Niebieskie nitki, nieprzywiązujących wagi do prozaicznych spraw, za jakie uważały posiłki. „Musia i Bunia zawsze miały tyle zajęć, że często w ogóle zapominały o posiłkach, traktując je jako nieistotny dodatek do pracy, czytania czy działalności społecznej” (Gutowska-Adamczyk, 2011: 26). Jednakże taką postawę krytykuje ich wnuczka, twierdząc: „Niedzielny obiad tworzy jednak atmosferę, której temu domowi zawsze brakowało (...)” (Gutowska-Adamczyk, 2011: 26).

Wymiar kulinarny gościnności reprezentowany przez estetykę przyrządzenia i podania jedzenia i napojów oraz społeczno-towarzyski w rozumieniu serdeczności wobec gości, otwartych gestów i dobrych słów, odpowiedniego stroju, jest na kartach powieści współczesnych dla młodego czytelnika sprawą coraz rzadszą. Przytoczone powyżej fragment prozy wskazują jednakże na więziotwórczą rolę spotkań przy stole, na autentyczną hojność gospodarzy płynącą z ich serc. Gotują najczęściej babcie, robią to samodzielnie, a mimo to, nie mając nawet takiego zamiaru, potrafią zarazić chęcią pomocy przebywających u nich wnuków. Natomiast $\mathrm{w}$ jednej powieści spotkać można gościnność rozumianą $\mathrm{w}$ wymienionym wymiarze $\mathrm{w}$ formie groteskowej, jako pusty rytuał wyraz snobizmu i fałszu. Już w biblijnej Księdze Przysłów $(23,6-8)$ ostrzega się przez obłudną gościnnością, gdy gospodarz nie daje $\mathrm{z}$ serca, lecz ma ukryte zamiary wobec gościa, a z kolei Ignacy Krasicki w satyrze Pijaństwo wyśmiewa brak umiaru. Rodzice Magdy z powieści Katarzyny Majgier Tajemnice starego pałacu. Duch z Niewiadomic, odkąd wygrali znaczną sumę pieniędzy, wszystko chcą mieć większe niż ich sąsiedzi. Dziewczynka nie rozumie ich zakłamanej gościnności, uczt wydawanych na pokaz, celebrowania posiłków, które nie zbliżają ludzi. „Magda się obawiała, że śniadanie potrwa do obiadu, który z kolei potrwa do kolacji i tym sposobem nie opuści jadalni" (Majgier, 2014: 52). Państwo ci o sugestywnym nazwisku Czereśniak są wymownym symbolem odwiecznego kołtuństwa, filisterstwa, wyrażających się w ignorancji wobec tradycji, niewrażliwością i bezrefleksyjnością wobec kultury i sztuki, a więc postawą konsumpcyjną i snobizmem. Przypominają rodzinę Dursleyów z Harry'ego Pottera czy Matyldy z powieści Roalda Dahla, co świadczy o szerszym społecznym problemie, a wobec tego tworzy ważny obszar do dyskusji na temat socjalizacyjnej funkcji rodziny, odpowiedzialności za wprowadzanie potomka w społeczeństwo, przekazywania mu zwyczajów, obyczajów, tradycji, w tym, jak pisał Adam Pisarek, gościnności w znaczeniu „dobrych obyczajów" i manier, wiążących się z określonymi wzorcami ucztowania, mową gestów, technikami posługiwania się ciałem i słowem, znaczącymi sekwencjami zachowań, a w szerszej perspektywie - godnością, honorem i wstydem jako ważnymi regulatorami zachowań (Pisarek, 2014: 10). 


\section{Gościnność w kontekście wsparcia i opieki}

O gościnności w wymiarze rodzinno-familijnym, rozumianej w sensie troskliwości, przychylności w obliczu kryzysowej sytuacji, mówi literatura piękna, wskazując na istotę funkcji opiekuńczej rodziny, jak też międzyludzkich więzi. Katarzyna Krasoń wymienia kilka przykładów klasyki dziecięcej, które traktuje jako wstęp do nauki o więziach międzyludzkich (między innymi: Muminki, Kubuś Puchatek) (Krasoń, 2001: 111), gdzie podstawą więzi w rodzinie są: miłość, ufność i dawania sobie przez domowników poczucia bezpieczeństwa. We współczesnej powieści dla młodego czytelnika Małgorzaty Gutowskiej-Adamczyk Niebieskie nitki (Gutowska-Adamczyk, 2011) problematyka koncentruje się wokół zagadnień związanych $\mathrm{z}$ utratą rodzinnego domu, zachwianego poczucia bezpieczeństwa $\mathrm{i}$ to $\mathrm{w}$ czterech kolejnych pokoleniach kobiet $\mathrm{w}$ rodzinie. Joanna, wraz $\mathrm{z}$ dorastającą córką Linką, w wyniku rozstania z mężem traci miejsce zamieszkania i decyduje się wrócić do rodzinnego domu. Rodzinny pałac jako miejsce zamieszkania wielu pokoleń jest symbolem ostoi i gościnności, wsparcia i przeczekania trudów, tu można znów poczuć się bezpiecznie, pozbierać myśli.

W słowniku synonimów znajdujemy rozumienie słowa gościnny jako przyjazny, serdeczny, życzliwy, otwarty, przychylny (Słownik synonimów polskich..., 2003: 120). Przychylność i otwarte serce okazuje Lince jej prababcia Bunia, stwarzając okazje do rozmów i zwierzeń, podobnie jak serdeczność i życzliwość okazuje Grześkowi Natalia - babcia Linki, wiedząc, że chłopak nie znajdzie takich uczuć w rodzinnym domu. Sama Linka maluje bardzo emocjonalne obrazy, których postacie połączone są niebieskimi nitkami - uczuciami, więziami, których nie da się odciąć. Ona też „odżywa”, kiedy do wigilijnego stołu zasiadają cztery pokolenia kobiet. Świąteczną atmosferę tworzy wspólnota, kiedy jest się autentycznie razem, a zastawiony stół jest atrybutem nie tyle obfitości, co pragnienia równowagi i stabilizacji.

Niestety, pozytywnej atmosfery i wzajemnego szacunku brakuje wśród dorosłych bohaterów powieści Grzegorza Kasdepke Poradnik hodowcy aniołów (Kasdepke, 2012). Bohaterka książki Marta razem z rodzicami i młodszym braciszkiem Rysiem mieszkają w bloku u siostry ojca. Ciocia Irena robi wyrzuty swoim gościom - rodzicom Marty, że nadużywają jej gościnności, ciążą jak w przysłowiach zapisanych w pierwszym słowniku języka polskiego Samuela Bogusława Lindego: „Gość częsty i długi rychło się sprzykrzy”, czy „Gość wiedzieć ma kiedy i na jak długi czas w gościnę jechać" (Linde, 1855: 103). Brak domu i związane z tym nadużywanie gościnności u bliskiej rodziny, brak swobodnej przestrzeni do życia, to szeroki problem społeczny, źródło konfliktów i wyrazu człowieczeństwa. Jest tu trochę jak w baśni ludowej (Jaś i Małgosia), kiedy to bieda i niedostatek wyzwalają w człowieku złe instynkty, żal i wzajemne pretensje. Jest jeszcze bardziej dramatycznie, kiedy 
świadkami scen rozdrażnienia dorosłych są dzieci. Brak własnego miejsca zamieszkania powoduje nerwowość i zamęczenie sobą nawzajem dorosłych, przy niezrozumieniu całej sytuacji przez dzieci, a Marta, bohaterka Poradnika hodowcy aniołów, jest wrażliwą, spragnioną uwagi dziewczynką. Ta mądra, pełna magii, ale też grozy książka pokazuje dorosłym, z jaką uważnością należy spędzać czas z dzieckiem, jak dbać o jego uczucia i marzenia.

$\mathrm{W}$ wymiarze rodzinno-familijnego rozumienia gościnności chciałam także zwrócić uwagę, w nieco przewrotny sposób, jak to dziecko nie jest gościem we własnym domu, ale jego członkiem, mając na myśli pierwsze trudne relacje z dzieckiem adoptowanym, kiedy to rodzice zaczynają od goszczenia go do tworzenia wspólnego gniazda.

We współczesnej prozie dla młodego czytelnika temat adopcji pojawia się coraz częściej ${ }^{1}$. Literatura, poruszając ten problem, pełni nade wszystko funkcję terapeutyczną, pomagając uporać się z lękami i obawami zarówno rodziców adopcyjnych, czujących się niepewnie w swojej nowej roli, jak i adoptowanych dzieci, które spotkały się z wieloma traumatycznymi przeżyciami. Rodzicom adopcyjnym Marka z powieści Ewy Nowak Bardzo biała wrona (Nowak, 2009) psycholog zwraca uwagę z powodu nadwrażliwości w obchodzeniu się z chłopcem i traktowania go na prawach gościa, a nie członka rodziny. „(...) Trzęsiecie się nad nim jak nad obcym dzieckiem. Swoje byście chowali inaczej, (...) dlaczego Natalia nie opiekuje się bratem? Dlaczego nie zostają nigdy razem? Dlaczego Marek nie chodzi do przedszkola? Dlaczego Wy nigdzie nie wychodzicie? Dlaczego oboje nie pracujecie?" (Nowak, 2009: 178). Znamienny ten cytat powoduje zastanowienie się całej rodziny nad zmianami metod postępowania z synkiem, próbę włączenia go $\mathrm{w}$ dotychczasowe funkcjonowanie rodziny, a nie traktowanie niejako „obok”, jak honorowego gościa, którego na dodatek bano się nie urazić. Rodziny adopcyjne, odmiennie niż rodzice biologiczni, jak pisała Antonina Gutowska „(...) którzy od chwili urodzenia dziecka są świadomi swoich praw, obowiązków i przywilejów, (...) nie są pewni swojej roli, zwłaszcza w początkowej fazie rodzicielstwa" (Gutowska, 2006: 12). Autorka powołuje się na badania kanadyjskiego socjologa Davida H. Kirka, który to wyróżnił dwa odmienne sposoby radzenia sobie $\mathrm{z}$ trudnościami związanymi $\mathrm{z}$ adekwatnym zdefiniowaniem swojej roli przez rodziców adopcyjnych: uznawanie różnic między rodzicielstwem adopcyjnym a naturalnym lub zaprzeczanie tym różnicom. Uznawanie różnic, jak pisze dalej A. Gutowska, „(...) wiąże się według D.H. Kirka z lepszym funkcjonowaniem rodziny adopcyjnej $\mathrm{w}$ aspekcie komunikacji między członkami rodziny i satysfakcji z adopcji" (Gutowska, 2006: 7). Oznacza to otwarte

\footnotetext{
${ }^{1} \mathrm{~W}$ powieści dla młodzieży temat adopcji poruszony został także u Joanny Jagiełło, Kawa z kardamonem; Marcela A. Marcela, Oro.
} 
mówienie o adopcji, stwarzanie okazji do wzajemnego poznawania uczuć członków rodziny, bezpośrednie stawianie czoła problemowi i staranie się o zrozumienie trudnej sytuacji zarówno swojej, jak i dziecka. Tak dzieje się w rodzinach z dwóch opowieści Katarzyny Kotowskiej: Jeż (1999) i Wieża z klocków (2001) oraz u Lucyny Landau w książce Witaj córeczko (2009). Rodziny adopcyjne prezentowane $\mathrm{w}$ wymienionych powieściach służą za wzorcowe modele reakcji, świadectwa miłości i traktowania dziecka w rozmowach jak równych sobie. „Na początku było im wszystkim bardzo trudno (...)”, na przykład „(...) chłopczyk Jeż znalazł się w nowym świecie i potrzebował czasu, by się poczuć bezpiecznie” (Kotowska, 1999). Jednakże, najlepszym dowodem na poczucie wrastania w rodzinę na prawach jej pełnoprawnego członka są słowa jednej z bohaterek - Mai: „(...) było mi bardzo przyjemnie, nie wiem, jak się czuje człowiek we własnej rodzinie, ale chyba mniej więcej tak, jak ja w tamtym momencie" (Kotowska, 1999: 53).

\section{O gościnności wobec kulturowo odmiennego}

Gościnność wydaje się mieć szczególne znaczenie w rozwoju człowieka w kontekście zaostrzających się konfliktów w wielokulturowym świecie. Chciałabym zwrócić uwagę na gościnność wobec „innego” w sensie zabłąkanego, zagubionego, stygmatyzowanego, społecznie i kulturowo odmiennego. Problem ten zasygnalizuję, bazując na analizie najnowszej polskiej literatury dla młodego czytelnika. Interesują mnie przykłady z literatury, która zwraca uwagę na kwestie odmienności społeczno-kulturowej bohaterów literackich, modeluje postawy wzajemnego dialogu, współpracy, wrażliwości kulturowej. W książce Ewy Grętkiewicz Szczękająca szczęka Saszy Sasza jest krewnym mieszkającym na stałe na Białorusi, jednakże na rok przyjeżdża do Polski, gdzie ma się posługiwać językiem polskim, jak też uczyć w polskiej szkole. Rodzice Karoliny, głównej bohaterki i narratorki opowieści, okazują radość z powodu jego przyjazdu, jak też proszą dwie córki o współpracę i pomoc $\mathrm{w}$ adaptacji chłopca do nowych warunków. „Mama i ja bardzo się cieszymy - powiedział ojciec - I liczę na to, że przyjmiecie Saszkę serdecznie. On nie ma rodziców, wychowuje go ciocia Teresa, która bardzo chce, żeby mówił po polsku" (Grętkiewicz, 2005: 15). Sam Sasza chce się uczyć języka polskiego, jest ciekawy polskich tradycji, niezauważalne są tu bariery adaptacyjno-akulturacyjne. Podobnie gości małego Titi mama Basi z książeczki Zofii Stanckiej Basia i kolega $z$ Haiti (2011), tłumacząc córce, skąd pochodzi Titi, co mu się przytrafiło, dlaczego chłopczyk jest taki zamknięty $\mathrm{w}$ sobie. Chłopczyk otwiera się, widząc serdeczność i otwarte przed nim serca, a tylko „życzliwość dla drugiej istoty może poruszyć w niej strunę człowieczeństwa”, jak 
mówił z okazji wręczenia tytułu doktora honoris causa Uniwersytetu Jagiellońskiego Ryszard Kapuściński, w kontekście doświadczenia przebywania latami wśród dalekich Innych (Kapuściński, 2004).

Jeszcze jeden przykład gościnnego, ciepłego domu, który, jak zauważyła Joanna Papuzińska, niezmiennie od lat emituje sygnały dobra w stronę wyziębłych i spragnionych serc, to dom Borejków z powieści Małgorzaty Musierowicz (Papuzińska, 1996: 17). Szczególną odwagą wykazały się dwie najmłodsze Borejkówny z powieści Noelka (Musierowicz, 2012: 131-132), przeciwstawiają się dorosłym, którzy wypędzili z kościoła ich małe rówieśnice, rumuńskie Cyganki-żebraczki, i zapraszając je do siebie na wigilijną kolację.

W trzech wymienionych powieściach rodzice są przewodnikami dzieci, uczą Levinasowskiego nie tylko stawania twarzą $\mathrm{w}$ twarz i prowadzenia dialogu, ale brania odpowiedzialności za gościa - innego kulturowo. Levinasowski model podmiotowości rozumiany jest jako gościnność, gościna, która przyjmuje drugiego człowieka. Przestrzeń, w której może rozwijać się gościnność, nazywa ten wybitny przedstawiciel filozofii dialogicznej przestrzenią będącą schronieniem, przystanią, azylem (Lévinas, 2002: 11-19). Sądzę, że takie są opisywane domy. Martin Buber mógłby dodać, że widoczne jest w postawie domowników „wejście w relację", "przyjęcie postawy dialogicznej” z człowiekiem kulturowo odmiennym. Wskazywał, że „miarę człowieka poznaje się po możności wejścia w dialogiczny związek" (Buber, 1993: 93).

W powieści, zatytułowanej Zupa z jeża Magdaleny Kozłowskiej przedstawiony został świat Romów w konwencji współczesnej baśni, ze szczególnym zaakcentowaniem ich przeszłości i tradycji, z tym, że autorka pokazuje niemożność porozumienia sąsiadujących ze sobą społeczności (Romów i gadziów) i przekroczenia pewnych granic kulturowych. Pisze: „Dwa światy, które powinny spotkać się wyłącznie podczas pracy jednych, a uciechy drugich!” (Kozłowska, 2012: 29).

Także książki o tematyce wojennej dla dzieci są wyrazem różnych postaw człowieka wobec człowieka zagrożonego utratą domu². Trudno znaleźć bardziej szlachetną postawę wobec drugiego człowieka niż tą reprezentowaną przez ojca Ponsa (Schmitt, 2009). Ten katolicki ksiądz ocalił w trakcie wojny tożsamość narodową dziesiątek goszczących (ukrywających się) w jego „żółtej willi” niczym

\footnotetext{
${ }^{2}$ Od roku 2011 Muzeum Powstania Warszawskiego z wydawnictwem Literatura wydało całą serię starannie opracowanych merytorycznie książek z cyklu "Wojny Dorosłych - Historie Dzieci”, służących do tego, by pokazać dzieciom, czym jest wojna, totalitaryzm, rasizm, zagłada i postawy ludzi wobec destrukcyjnej mocy nienawiści. Wymienić należy tu: Joanny Papuzińskiej Asiunię; Michała Rusinka Zaklęcie na „w”; Pawła Beręsewicza, Czy wojna jest dla dziewczyn?; Doroty Combrzyńskiej-Nogal Bezsenność Jutki; Beaty Ostrowickiej Jest taka historia. Opowieść o Januszu Korczaku. Poza serią powstały także powieści: Joanny Rudniańskiej Kotka Brygidy; Iwony Chmielewskiej Pamiętnik Blumki; Marcina Szczygielskiego Arka czasu; Joanny Papuzińskiej Mój tato szczęściarz; Pawła Beręsewicza Wszystkie lajki Marczuka; Joanny Concejo Dym czy Natalii Gancarz Mietek na wojnie.
} 
w Arce Noego, żydowskich dzieci. Uczył ich hebrajskiego, Tory, łamania barier dzielących dwie monoteistyczne religie i traktował jak własne dzieci, chroniąc przed „szaleństwem innych ludzi” (Schmitt, 2009: 128). Mówił: „(...) jeżeli potop będzie trwał, jeżeli w całym kosmosie nie uchowa się ani jeden Żyd mówiący po hebrajsku, będę cię mógł nauczyć tego języka. A Ty przekażesz go innym” (Schmitt, 2009: 71). Jeszcze raz należy podkreślić, że trudno o budzącą większy szacunek postawę gościnności, mądrości i sprawiedliwości. Dzięki takim osobom, które z narażeniem własnego życia przyjmowały, chroniły, ukrywały pod swoim dachem prześladowanych, można wierzyć w ludzką bezinteresowność i dobroć.

W jeszcze innej powieści dla młodzieżowego odbiorcy zaznaczony został problem gospodarki mieszkaniowej czasów PRL, kiedy to wielu właścicielom zabierano lokale, kamienice lub poddawano je obowiązkowi kwaterunku. Prawnuczka nie może wprost uwierzyć, że ich dom był niegdyś zamieszkiwany przez przymusowych lokatorów. Mówi:

- Chcesz powiedzieć, że siedzieli wam na karku przez trzydzieści lat jacyś nieproszeni goście, a wy ich teraz przyjmujecie ciasteczkami i kawą?!

- To nie była ich wina. Nie mieli dachu nad głową (...). (Gutowska-Adamczyk, 2011:44)

Powołując się na głos etyki niezależnej Tadeusza Kotarbińskiego, wiemy, że stanowiska opiekuńczości i odpowiedzialności człowiek zacny i porządny powinien przyjmować nie tylko wobec tych, z którymi jest związany emocjonalne czy umową, ale także wobec osób obcych, które potrzebują pomocy i są od nas faktycznie zależne (Kotarbiński, 1989). Sytuacja w której znalazła się prababcia, nie była do pozazdroszenia, była sytuacją przymusową, oczekiwano od właścicielki podzielenia się jej prawną wartością - domem, jednakże mimo przymusu ocaliła ona swoją godność, a lokatorom okazała serce. Wzruszające są słowa, jednego z takich „gości”, który to po latach wrócił do ojczyzny i odwiedził dom, w którym mieszkał: „nigdzie nie czułem się tak dobrze, jak tu!" (Gutowska-Adamczyk, 2011: 44).

\section{Uwagi końcowe}

W tekście była mowa o gościnności rozumianej w trzech wymiarach. Po pierwsze, w wymiarze kulinarnym i społeczno-towarzyskim, w sensie uprzejmości częstowania „jadłem i napojem” (najczęstsze rozumienie gościnności, kiedy to troska o bliźniego jest wyrażana poprzez wspólne spożywanie przygotowanego dla niego posiłku). W tym przypadku o gościnności mówić także prześmiewczo, gdyż w wielu powieściach niedzielne i świąteczne „zjazdy obiadowe” są pustym rytuałem. Po drugie, była mowa o gościnności w wymiarze rodzinno-familijnym, w sensie goszczenia swoich dorosłych dzieci, kiedy to trzeba nauczyć się żyć razem, 
od nowa, w warunkach zmian spowodowanych rodzinnymi zawirowaniami. W tym wymiarze zwróciłam uwagę, w nieco przewrotny sposób, jak to dziecko nie jest gościem we własnym domu, ale jego członkiem, mając na myśli pierwsze trudne relacje $\mathrm{z}$ dzieckiem adoptowanym, kiedy to rodzice zaczynają od goszczenia go, do tworzenia wspólnego gniazda. Wyeksponowałam jeszcze jedno rozumienie gościnności, bardzo aktualne w obecnej sytuacji społeczno-politycznej, zaostrzającego się prawa dotyczącego mniejszości etnicznych i religijnych na terenie Europy Zachodniej - rozumienie gościnności w aspekcie kulturowym, gościnności wobec „innego” w sensie zabłąkanego, zagubionego, kulturowo odmiennego.

W kontekście analizowanych tekstów, rodzi się ważne pytanie w obliczu obecnie trwającego globalnego kryzysu wartości: jak rozmawiać z dzieckiem o granicach gościnności i związanej z nią granicy tolerancji?

Adam Pisarek zwrócił uwagę, że w kulturze polskiej „(...) gościnność rozumiana jako serdeczność i bezinteresowna życzliwość okazywana przybyszom (...) jest uznawana za jedną z najbardziej wartościowych postaw wobec drugiego człowieka" (Pisarek, 2014). W dyskursie publicznym gościnność pojawia się najczęściej „(...) w odniesieniu do wędrowania, pielgrzymowania, turystyki i innych form kontaktu kulturowego, w tym dyplomacji i polityki migracyjnej" (Pisarek, 2014).

Gościnność jest rozumiana także jako rozszerzenie domu, gdzie gość ma poczuć się jak u siebie w domostwie, z tym, że przestrzeganie obowiązków, tak jak w każdej innej przestrzeni społecznej, jest w tym przypadku także koniecznością. Obowiązkiem podstawowym jest obopólny szacunek, a więc gościa wobec gospodarza, jak też gospodarza wobec gościa. Można mówić niezrozumiałym językiem, zachowywać się w niezrozumiały sposób, jednakże tolerowane nie może być łamanie praw, przynoszenie cierpienia innym, krzywdy czy upokorzenia, jednym słowem barbarzyństwo (Środa, 2008: 35).

Przedstawione powyżej współczesne powieści skierowane do dzieci i młodzieży mogą stanowić pomoc w rozwoju i edukacji młodego człowieka w kierunku postawy gościnności jako wartości moralnej, z którą związane są inne wartości, takie jak opiekuńczość, troskliwość, życzliwość, łaskawość, czułość, odpowiedzialność wobec drugiej osoby, gościa, potrzebującego.

\section{Literatura}

Banach C. (2001). Edukacja, wartość, szansa. Kraków.

Bańkowski A. (2000). Etymologiczny słownik języka polskiego, t. 1. Warszawa.

Brückner A. (1974). Słownik etymologiczny języka polskiego. Warszawa.

Buber M. (1993). Problem człowieka. Warszawa.

Cybal-Michalska A. (2011). Globalizacja i jej krytyka. O potrzebie zorientowania społeczeństwa na wiedzę, aktywne współdziałanie i odpowiedzialność. [W:] A. Cybal-Michalska (red.). Dyskursy kultury popularnej w społeczeństwie współczesnym. Kraków. 
Gloger Z. (1985). Encyklopedia staropolska ilustrowana, t. 2. Warszawa.

Grętkiewicz E. (2005). Szczękająca szczęka Saszy. Warszawa.

Gutowska A. (2006). Specyfika rodzicielstwa adopcyjnego w świetle teorii Davida H. Kirka. „Roczni-

ki Psychologiczne" t. IX, nr 2, s. 12.

Gutowska-Adamczyk M. (2011). Niebieskie nitki. Warszawa.

Herder J.G. (1962). Myśli o filozofii dziejów, t. II. Warszawa.

Hildebrand D. (1982). Fundamentalne postawy moralne. [W:] D. Hildebrand, J.A. Kłoczowski, J. Paściak, J. Tischner. Wobec wartości. Poznań.

Homplewicz J. (1996). Etyka pedagogiczna. Rzeszów.

Jędrych K. (2014). O znaczeniu jedzenia w wybranych książkach Marii Kruger. [W:] B. Niesporek-Szamburska, M. Wójcik-Dudek (red.). Wyczytać świat - międzykulturowość w literaturze dla dzieci i młodzieży. Katowice.

Kapuściński R. (2004). Spotkanie z Innym - jako wyzwanie XXI wieku. „Gazeta Wyborcza” 1.10.

Kasdepke G. (2012). Poradnik hodowcy aniołów. Łódź.

Kotarbiński T. (1989). Żyć zacnie. Warszawa.

Kotowska K. (1999). Jeż. Warszawa.

Kotowska K. (2001). Wieża z klocków. Poznań.

Kozłowska M. (2012). Zupa z jeża. Gdynia.

Krasoń K. (2001). Antropomorfizowany obraz interakcji jako literacka propedeutyka więzi. [W:]

A. Baluch (red.). Sezamie otwórz się. Kraków.

Kurzowa Z. (red.). (2003). Słownik synonimów polskich. Warszawa.

Landau L. (2009). Witaj córeczko. Łódź.

Lévinas E. (2002). Całość i Nieskończoność. Warszawa.

Linde S.B. (1855). Słownik języka polskiego, t. 2. Lwów.

Majgier K. (2014). Tajemnice starego pałacu. Duch z Niewiadomic. Warszawa.

Musierowicz M. (2012). Noelka. Łódź.

Nowak E. (2009). Bardzo biała wrona. Warszawa.

Olbrycht K. (2000). Prawda, dobro i piękno w wychowaniu człowieka jako osoby. Katowice.

Ostrowicka B. (2002). Niezwykłe wakacje. Łódź.

Papuzińska J. (1996). Dziecko w świecie emocji literackich. Warszawa.

Pisarek A. (2014). Gościnność polska. Próba interpretacji antropologicznej, (praca doktorska), www.sbc.org.pl/Content/126577/doktorat3489.pdf, dostęp: 5.05.2016.

Podstawa programowa kształcenia ogólnego dla szkół podstawowych z dnia 23 grudnia $2008 \mathrm{r}$. I etap edukacyjny: klasy I-III, edukacja wczesnoszkolna.

Puzynina J. (1992). Język wartości. Warszawa.

Schmitt E.E. (2009). Dziecko Noego. Kraków.

Stanecka Z. (2011). Basia i kolega z Haiti. Warszawa.

Szczygielski M. (2013). Czarownica piętro niżej. Warszawa.

Szyszko-Kondej M. (2008). Sejf z milionem $w$ środku czyli bestseller III $b$. Warszawa.

Środa M. (2008). Postawy wobec obcości. Kim sa obcy. [W:] K. Czyżewski (red.). Warto zapytać o kulturę. Inny, obcy, swój. Sejny.

Świrko S. (1985). Na wszystko jest przysłowie. Poznań.

Wiszowata A. (2015). Sam i Riko. Gdynia.

Witek R. (2013). Klub latających ciotek. Kraków. 